\title{
CONTINUOUS PROFESSIONAL DEVELOPMENT IN HEALTHCARE
}

\author{
A A Ngurah. Bagus. Aristayudha ${ }^{1}$ \\ Ni Made Widnyani ${ }^{2}$ \\ Vitalia Fina Carla Rettobjaan ${ }^{3}$
1,2,3 Fakultas Bisnis Sosial Teknologi dan Humaniora Program Study Bisnis
Digital Universitas Bali Internasional \\ email: aristayudha17@gmail.com
}

\begin{abstract}
ABSTRAK
Industry 4.0 telah memperlihatkan bahwa digital ada dimana mana. Industri Healtcare dalam termasuk dalam cluster "long fuse, big bang" yang berarti perusahaan akan menghadapi gangguan mereka dalam tiga hingga lima tahun dan karenanya memiliki lebih banyak waktu untuk berubah (Deloitte 2015). Yang memperlihatkan bahwa dalam beberapa tahun akan terjadi transformasi cara industri healtcare berjalan. Penelitian ini dilakukan bertujuan untuk mengetahui pengaruh continued professional development (CPD) dalam industri healtcare. Sampel dalam penelitian ini adalah 107 orang dimana hasil pengumpulan data diolah menggunakan teknik analisis Regresi linier sederhana. Hasil penelitian membuktikan bahwa continued professional development berpengaruh positif dan signifikan terhadap individu di dalam industri healtcare dan continued professional development berpengaruh positif dan signifikan terhadap organisasi di dalam industri healtcare. Hal ini menunjukkan Organisasi/perusahaan dalam industri healtcare diharapkan mengambil tanggung jawab untuk pengembangan kemampuan karyawan serta Individu/karyawan dalam industri healtcare diharapkan memahami bahwa CPD merupakan investasi dalam pengembangan karir.
\end{abstract}

Kata Kunci: continued professional development, motivasi, persepsi, manfaat

\section{ABSTRACT}

Industry 4.0 has shown that digital is everywhere. The Healtcare industry is in the "long fuse, big bang" cluster meaning companies will face their disruption in three to five years and therefore have more time to change (Deloitte 2015). Which shows that in a few years there will be a transformation in the way the health care industry works. This study was conducted to determine the effect of continued professional development (CPD) in the health care industry. The sample in this study were 107 people where the results of data collection were processed using simple linear regression analysis techniques. The research results prove that continued professional development has a positive and significant effect on individuals in the health care industry and that continued professional development has a positive and significant effect on organizations in the health care industry. This shows that organizations / companies in the health care industry are expected to take responsibility for the development of employees' abilities and individuals / employees in the health care industry are expected to understand that CPD is an investment in career development.

Keywords: continued professional development, motivation, perception, benefits 


\section{PENDAHULUAN}

Industry 4.0, AI, Cloud computing, the internet of everything, $3 d$ printing, social networking, ubiquitous connectivity dan big data serta lain sebagainya telah memperlihatkan bahwa digital ada dimana mana. Masing-masing dari hal tersebut telah mengubah cara kita berkomunikasi, berinteraksi, bekerja dan hidup, tapi ini baru permulaan, karena beberapa industri telah terdistrupsi dalam value chain, struktur organisasi, proses operasional, dan model pendapatan dalam bisnis pendek atau keseluruhan. (Deloitte, 2015). Peta distrupsi global kami memperlihatkan 17 industri klaster dan skenario fuse/bang setiap klasternya. Industri healtcare dalam termasuk dalam cluster "long fuse, big bang" yang berarti perusahaan akan menghadapi gangguan mereka dalam tiga hingga lima tahun dan karenanya memiliki lebih banyak waktu untuk berubah (Deloitte, 2015). Yang memperlihatkan bahwa dalam beberapa tahun akan terjadi transformasi cara industri healtcare berjalan.

Diperkirakan bahwa pembelajaran menghasilkan perubahan, yang memengaruhi aktivitas organisme (Schacter D.L., et al., 2011). Beberapa percaya bahwa semua kehidupan memiliki kemampuan untuk belajar dan beradaptasi tidak hanya mamalia tetapi termasuk juga organisme lain di dalam kehidupan (Karban, 2015). Pembelajaran dapat didefinisikan sebagai konstruksi hipotesis yang tidak dapat diamati secara langsung, tetapi hanya tersirat dari mengikuti pola perilaku selama periode waktu tertentu. oleh karena itu, jika perubahan perilaku harus dihitung sebagai pembelajaran, perubahan tersebut harus dikaitkan dengan beberapa jenis pengalaman terlepas dari apakah ada upaya untuk melakukan perubahan itu. (Gross., 2010)

Untuk bertahan dan tetap relevan, perusahaan sekarang harus cepat beradaptasi dengan pasar yang terus berubah. Keuntungan kompetitif berkelanjutan semakin menjadi tentang benar-benar pandai belajar bagaimana melakukan hal-hal baru. Selain perusahaan, individu juga harus menyesuaikan keterampilan mereka agar tetap relevan di pasar kerja. Era digital menuntut individu untuk menjadi pembelajar seumur hidup (Casse et al., 2017). Mengingat ketidakpastian seputar industri Healtcare, industri bisnis berjuang untuk mengembangkan strategi yang dapat memandu posisi pasar dan persaingan jangka pendek dan jangka panjang (Fuld Company 2018)

CPD adalah aspek penting dari pembelajaran seumur hidup yang memiliki manfaat pribadi dan organisasi. Manfaat pribadi adalah yang dirasakan oleh tenaga kesehatan, sedangkan manfaat organisasi adalah manfaat untuk organisasi (Panthi \& Pant, 2018). Continued professional development (CPD) telah menjadi pusat pengembangan kapasitas di organisasi paling sukses di negara-negara barat selama beberapa dekade terakhir. Profesi khusus di bidang terus berkembang, yang mengharuskan standar tertentu untuk diikuti melalui pendaftaran dan sertifikasi (Weerakkody et al., 2016).

Diyakini bahwa CPD yang berkelanjutan dapat membantu dalam mencapai pembelajaran seumur hidup karena itu, itu harus menjadi tindakan berkelanjutan sukarela yang berlangsung sepanjang hidup sehingga individu menjadi bertanggung jawab kepada diri mereka sendiri dan masyarakat mereka (Laal \& Salamati, 2012). Kompetensi ini dikembangkan melalui berbagai kegiatan pengembangan 
profesional berkelanjutan (Hariyati \& Safril, 2018). CPD menguntungkan perawatan pasien, organisasi dan individu dan itu membawa kepuasan kerja yang lebih tinggi, retensi pekerjaan dan stres yang lebih rendah (Panthi \& Pant, 2018).

Dalam bentuknya yang paling mudah dikenali, CPD mungkin memperbarui pengetahuan profesional melalui kursus singkat dan formal oleh kelompokkelompok pekerjaan seperti, misalnya, dokter, pengacara, dan guru. Biasanya kelompok-kelompok ini memiliki badan atau lembaga profesional mereka sendiri dan mungkin keanggotaan dan sertifikat praktik yang dikeluarkan oleh badan ini merupakan prasyarat untuk mempraktikkan profesi (Collin et al., 2012). CPD adalah proses berkelanjutan yang membantu seseorang untuk berkembang sebagai praktisi profesional. CPD terjadi dengan berada dalam profesi dan memperoleh kompetensi baru yang diperlukan untuk memenuhi tantangan yang muncul selama profesi. (Jasper 2011) CPD untuk profesional kesehatan diperkenalkan selama 1990-an di Kanada. Pada saat itu orang Kanada menuntut sistem perawatan kesehatan yang akan memenuhi kebutuhan mereka (Fleet et al., 2008). Menurut (James \& Francis, 2011), CPD adalah penting untuk semua tenaga kesehatan di mana perawatan pasien dan klien yang berkualitas tinggi ditunjukkan. CPD adalah pembelajaran seumur hidup yang terjadi setelah gelar atau kualifikasi dan berusaha untuk memenuhi kebutuhan pasien saat ini dan meningkatkan pemberian perawatan kesehatan sehingga memberikan perawatan yang berkualitas kepada pasien (Thomas, 2008).

CPD juga merupakan upaya untuk meningkatkan kualitas layanan kesehatan dan diyakini untuk mentransfer pengetahuan baru sehingga profesional kesehatan tidak hanya mendapatkan keterampilan tetapi juga memberikan perawatan yang optimal kepada pasien meningkatkan hasil pasien (Légaré et al., 2017). Banyak faktor yang mempengaruhi perawat untuk berpartisipasi dalam CPD. (Taylor, 2016) telah menemukan faktor-faktor yang mempengaruhi adalah perolehan ekonomis, promosi pekerjaan dan imbalan finansial.

CPD yang berkesinambungan berfungsi untuk mempertahankan dan memperoleh pengetahuan dan keterampilan saat ini dalam lingkungan perawatan kesehatan yang berubah dengan cepat. ( Pryce-Miller 2015) Oleh karena itu, dengan teknologi yang terus berubah, profesional kesehatan berkomitmen untuk memperoleh keterampilan dan sikap baru, memperbarui pengetahuan serta kompeten dalam prosedur dan penilaian klinis. (Panthi \& Pant, 2018). Berdasarkan latar belakang di atas, peneliti tertarik untuk melakukan penelitian "Continued professional development dalam industri healtcare".

Berdasarkan latar belakang di atas adapun rumusan masalah dalam penelitian ini adalah apakah pengaruh continued professional development dalam industri healtcare?. Adapun tujuan penelitian ini adalah untuk mengetahui continued professional development dalam industri healtcare. Untuk mengetahui apa manfaat individu dan organisasi yang mempengaruhi continued professional development dalam industri healtcare?. Untuk mengetahui apa motivasi individu dan organisasi yang mempengaruhi continued professional development dalam industri healtcare?. Untuk mengetahui apa persepsi individu dan organisasi yang mempengaruhi continued professional development dalam industri healtcare? 
Adapun manfaat penelitian ini adalah manfaat praktis yaitu hasil penelitian ini dapat menjadi sumber informasi bagi perusahaan terkait continued professional development dalam industri healtcare. Manfaat teoritis yaitu hasil penelitian bisa menjadi sumber informasi tambahan dalam memperkuat hasil-hasil studi tentang continued professional development dalam industri healtcare.

Kita hidup di era informasi (a.k.a digital age), yang merupakan periode dalam sejarah manusia yang ditandai oleh pergeseran dari produksi industri ke yang didasarkan pada informasi dan komputerisasi, mengubah cara orang berinteraksi dengan bisnis dan satu sama lain. Saat ini, informasi sudah tersedia dan gratis. Democratization akses terhadap informasi telah menghasilkan pergeseran distribusi kekuasaan antara pemerintah dan warga negara, pengecer dan konsumen, manajer dan karyawan, guru dan siswa. Konsekuensi lain adalah bahwa, sekarang, ada terlalu banyak informasi untuk ditangani oleh satu orang, dan informasi itu menjadi usang dengan sangat cepat. Akses terus menerus, tepat waktu ke informasi terbaru telah menjadi yang terpenting bagi semua pelaku masyarakat. Zaman digital adalah zaman pelanggan yang diberdayakan. Konsumen yang diberdayakan sekarang dapat membuat pilihan cerdas tentang produk yang tepat untuk situasi yang tepat dengan semua data yang relevan, tepat pada waktunya. Di zaman baru ini konsumen, bukan merek, mengontrol interaksi. Untuk bertahan dan tetap relevan, perusahaan sekarang harus cepat beradaptasi dengan pasar yang terus berubah (Casse et al., 2017).

Selama abad terakhir, pengembangan dan pengujian teori pembelajaran telah membantu memahami bagaimana menjangkau individu yang berbeda dan mengubah metode berpikir, perasaan, dan perilaku mereka (Driscoll 2005). Teori belajar memiliki kegunaan dan kepraktisan yang luar biasa dalam pendidikan dan psikologi. Disarankan untuk menggunakan teori pembelajaran, tunggal, terpisah atau kombinasi keduanya dalam bidang kepedulian (Sobhaninejad 2005). Teori belajar dapat digunakan secara individual dalam kelompok atau di tingkat masyarakat. Mereka tidak hanya membantu dalam memahami hal-hal baru, tetapi juga membantu dalam pemecahan masalah, mengubah kebiasaan kesehatan, komunikasi konstruktif, mengendalikan emosi dan perubahan perilaku dan perkembangan. (Quinn 2007).

Untuk melibatkan peserta/pembelajar, pembelajaran juga harus bermakna dan relevan, untuk pelajar dan organisasi. Dalam membidik keterlibatan penuh, penting bagi peserta didik untuk menganggap kegiatan sebagai kegiatan yang berarti bagi diri mereka dan organisasi mereka. Penelitian telah menunjukkan bahwa jika peserta didik tidak menganggap kegiatan pembelajaran layak waktu dan usaha mereka, mereka mungkin tidak terlibat dengan cara yang memuaskan, atau bahkan mungkin melepaskan diri sepenuhnya sebagai respons (Fredricks et al., 2004). Untuk memastikan bahwa kegiatan itu bermakna secara pribadi, kita perlu membantu peserta didik kita terhubung dengan apa yang relevan bagi mereka, seperti, aktivitas atau konteks kerja mereka, jaringan teman sebaya, atau tujuan pembelajaran pribadi. (Casse et al., 2017)

CPD adalah konsep yang lebih luas untuk melanjutkan pengembangan kompetensi beragam yang melekat dalam praktik medis termasuk mata pelajaran medis, manajerial, sosial dan pribadi yang diperlukan untuk kinerja profesional 
berkualitas tinggi dalam sistem pemberian perawatan kesehatan modern. CPD adalah pelengkap untuk pendidikan formal sarjana dan pascasarjana; menyelesaikan trilogi pendidikan. Pendidikan kedokteran sarjana dan pascasarjana diatur oleh aturan dan peraturan khusus tetapi CPD adalah proses di mana tanggung jawab terletak pada para profesional dan individu (Khan, 2010). Continuing Professional Development (CPD) adalah tentang memastikan bahwa individu memiliki peluang untuk mengikuti perkembangan tren dan terus-menerus mempelajari dan meningkatkan subjek dan pengetahuan profesional mereka (Moonasar \& Underwood, 2018) Orang-orang mengharapkan apa yang 'terbaik' daripada apa yang 'tepat' untuk situasi tertentu dan untuk tingkat itu; kompetensi profesional harus dikombinasikan dengan improvisasi dan pengawasan umum. Itulah sebabnya, di seluruh dunia konsep CPD muncul dan berkembang sebagai proses pendidikan yang dinamis untuk meningkatkan dan meningkatkan kinerja profesionalnya (Khan, 2010).

CPD yang berhasil tergantung pada implementasi prinsip-prinsip berikut. Mengenai lokakarya itu sendiri: tujuannya harus perbaikan umum pendidikan; perencanaan lokakarya yang formal dan sistematis; menyatakan dan mengklarifikasi tujuan lokakarya; fokus pada pemikiran kritis, refleksi dan pengarahan diri sendiri; mengembangkan keunggulan melalui kompetensi, kepercayaan diri, kenikmatan, dan kebutuhan kontekstual (Lessing \& Witt, 2007). CPD adalah proses pendidikan di mana anggota dari profesi apa pun mempertahankan, meningkatkan, dan memperluas pengetahuan, keterampilan, dan kualitas pribadi yang diperlukan dalam kehidupan profesional mereka. Ini adalah komitmen holistik untuk peningkatan keterampilan terstruktur dan kompetensi pribadi atau profesional. CPD juga dapat didefinisikan sebagai pembaruan pengetahuan profesional secara sadar dan peningkatan kompetensi profesional di sepanjang kehidupan kerja seseorang. Ini adalah kunci untuk mengoptimalkan peluang karier seseorang, baik hari ini dan untuk masa depan (Khan, 2010). CPD diperlukan untuk memberdayakan kepercayaan diri, pengetahuan dan keterampilan. Untuk mencapai keberhasilan, pengembangan tersebut harus mematuhi prinsip-prinsip tertentu dan memenuhi kriteria tertentu (Lessing \& Witt, 2007). CPD merupakan aspek penting dari pembelajaran seumur hidup yang memiliki manfaat pribadi dan organisasi (Panthi \& Pant, 2018).

CPD adalah investasi yang dilakukan dalam diri untuk mempercepat pengembangan karir. Ini memberikan dampak meningkatkan efektivitas profesional dan peluang karier. Ini akan meningkatkan kepercayaan diri dan memperkuat kredibilitas profesional untuk mempersiapkan diri untuk tanggung jawab yang lebih besar dan dapat melihat perkembangan dengan melacak pembelajaran. Ini akan membantu menjadi lebih kreatif dalam menghadapi tantangan baru dan akan mampu menghadapi perubahan secara positif dengan terus memperbarui pengetahuan dan keterampilan. Dengan CPD dapat mengidentifikasi kesenjangan dalam pengetahuan dan pengalaman. CPD membuat kehidupan kerja lebih menarik dan secara signifikan dapat meningkatkan kepuasan kerja dan mencegah 'kelelahan' (Khan, 2010).

Ketika organisasi mengalihkan tanggung jawab untuk pengembangan pribadi kembali ke individu, kemampuan dan wawasan untuk mengelola pertumbuhan 
profesional kita dipandang sebagai kekuatan utama. CPD akan memaksimalkan potensi staf dengan menghubungkan pembelajaran dengan tindakan dan teori dengan praktik. Ini mengarah pada moral staf yang lebih baik dan tenaga kerja yang termotivasi membantu memberikan citra atau merek yang positif bagi organisasi. Ini adalah alat yang baik untuk membantu karyawan memfokuskan pencapaian mereka sepanjang tahun (Khan, 2010).

Konsep Teori Hierarchy of Needs Abraham Maslow, Abraham Maslow (1908-1970) adalah seorang psikolog besar yang mencoba menemukan dan menawarkan jawaban sistematis atas pertanyaan melalui teorinya yang tersohor, yakni teori hierarki kebutuhan. Menurut Maslow, setiap individu memiliki kebutuhan-kebutuhan yang tersusun secara hierarki dari tingkat yang paling mendasar sampai pada tingkat yang paling tinggi. Setiap kali kebutuhan pada tingkatan paling bawah terpenuhi maka akan muncul kebutuhan lain yang lebih tinggi. Keseluruhan teori motivasi yang dikembangkan oleh Maslow berintikan pendapat yang mengatakan bahwa kebutuhan manusia itu dapat diklasifikasikan pada lima hierarki kebutuhan yaitu : kebutuhan fisiologis, kebutuhan akan keamanan, kebutuhan social, kebutuhan "esteem" dan kebutuhan untuk aktualisasi diri (Siagian, 2012).

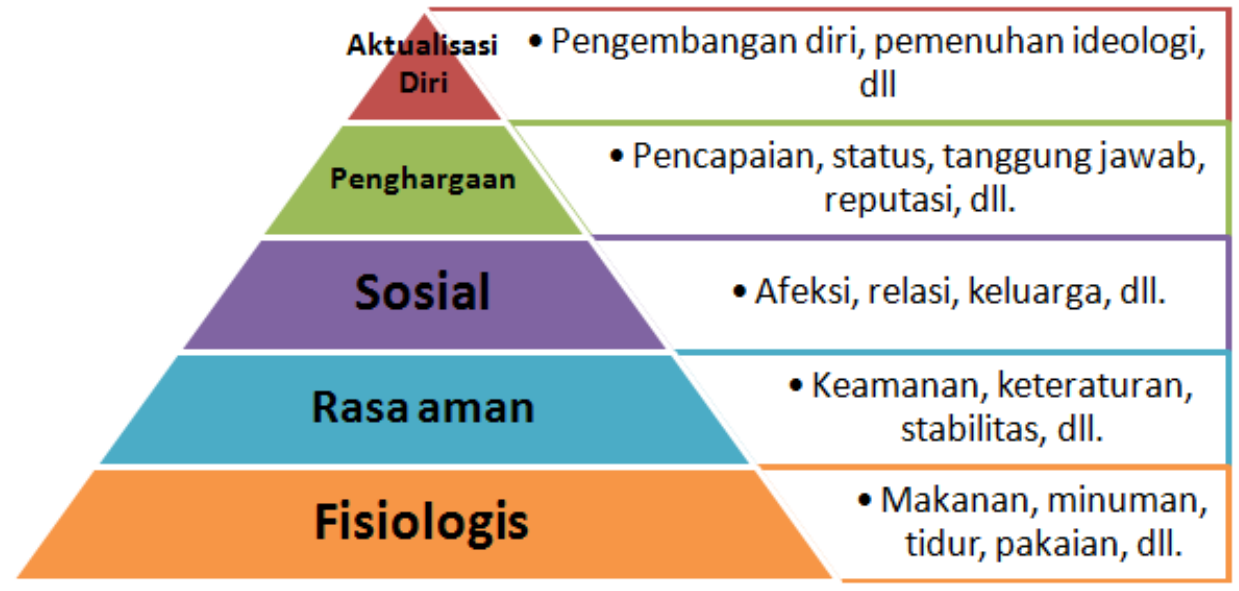

\section{Gambar 1. Teori Hierarchy of Needs}

Level pertama dari hierarki kebutuhan manusia adalah physiological needs atau kebutuhan fisiologi kita. Level ini terdiri dari kebutuhan - kebutuhan fisik yang paling mendasar dan adalah hal - hal yang kita perlu untuk tetap hidup. Ini termasuk makanan, minuman, tempat berteduh, tidur, dan oksigen (sandang, pangan, papan). Sebelum bisa menangani kebutuhan yang lain, kebutuhan fisiologi manusia harus ditangani dulu; seorang yang sedang benar - benar kelaparan tidak akan memikirkan reputasi mereka ataupun mencari teman. Dalam konteks bisnis, kebutuhan ini bisa dipuaskan dengan cara membayar karyawan dengan pembayaran yang cukup tinggi agar mereka mampu membiayai keperluan dasar mereka.

Setelah memenuhi kebutuhan level pertama, maka kita bisa mulai mencoba memuaskan kebutuhan level kedua, safety needs atau kebutuhan akan keamanan. Keamanan disini bukan cuma berarti secara fisik (walau itu juga termasuk dalam level ini) tetapi juga mengenai rasa keamanan. Artinya, selain keamanan fisik, 
kebutuhan ini juga termasuk stabilitas dan ketergantungan, sekaligus perlindungan dari kriminalitas, terorisme, perang, penyakit, bencana alam, dan lain - lain. Keamanan juga termasuk keamanan secara mental seperti kebebasan dari rasa takut, stres, dll. Bila kita tidak merasa aman, maka kita tidak akan memikirkan kebutuhan sosial, maupun kebutuhan akan dihargai orang lain. Dalam konteks bisnis, kebutuhan ini bisa dipenuhi dengan kontrak kerja agar mereka mendapat jaminan kerja. Untuk beberapa orang, organisasi yang terstruktur juga dapat memuaskan kebutuhan level ini karena dapat memberi mereka perasaan stabilitas. Peraturan juga mungkin membantu perasaan stabilitas.

Setelah kebutuhan fisiologi terpenuhi dan kita sudah merasa aman, maka berikutnya adalah kebutuhan kita untuk merasakan kasih sayang sekaligus perasaan memiliki dan dimiliki, atau social needs. Yang dimaksud adalah kebutuhan manusia untuk merasa dibutuhkan agar dianggap sebagai warga komunitas sosialnya. Kebutuhan ini bisa termasuk keinginan untuk bersahabat, atau untuk memiliki pasangan dan keturunan, kebutuhan untuk dekat pada keluarganya, dan juga keinginan memberi dan menerima cinta. Dalam konteks bisnis, kebutuhan ini bisa dipenuhi dengan memberikan kesempatan untuk para karyawan bekerja bersama dan bersosialisasi. Ini bisa dilakukan dengan menugaskan pekerjaan kelompok atau juga bisa menjadwalkan rekreasi bersama.

Setelah mereka merasa bahwa kebutuhan fisiologi mereka terpenuhi, keamanan mereka terjamin, dan bahwa mereka adalah warga dari komunitas sosial mereka, mereka akan memiliki esteem needs, atau kebutuhan untuk dihargai. Kebutuhan ini adalah kebutuhan egonya atas keinginan untuk berprestasi dan memiliki prestise. Ini dapat termasuk keinginan untuk dihormati orang lain, ketenaran, pengakuan, perhatian, reputasi, dan kepemilikan status. Selain kebutuhan eksternal, manusia juga akan membutuhkan keyakinan pada diri sendiri, kompetensi, prestasi, kemandirian, kebebasan, dan penguasaan. Dalam konteks bisnis, kebutuhan ini bisa kita realisasikan dengan mengakui pekerjaan - pekerjaan yang karyawan kita kerjakan; saat mereka melakukan sesuatu yang bagus atau saat mereka berhasil, kita harus meyakinkan mereka bahwa kita mengakui pencapaian itu. Selain itu, kita juga bisa beri promosi, status, atau pujian di depan karyawannya yang lain.

Setelah semua kebutuhan diatas terpenuhi, maka kita akan mencapai kebutuhan akan aktualisasi sendiri, atau self-actualization needs. Kebutuhan ini adalah mengenai membuktikan dan menunjukan diri kepada orang lain. Untuk melakukan itu, kita akan mengembangkan diri sendiri semaksimal mungkin segala potensi yang kita miliki. Untuk menjadi yang terbaik yang kita bisa, itulah tujuan kebutuhan ini. Tidak banyak orang yang bisa mencapai tahap ini, karena banyak dari kita yang memiliki kebutuhan yang belum terpenuhi. Kebutuhan tingkat ini berbeda dengan kebutuhan - kebutuhan sebelumnya. Kita tidak ingin lagi dihargai orang lain, maupun ingin persahabatan ataupun cinta mereka. Pada tahap ini, apa yang kita lakukan adalah untuk membuktikan pada diri sendiri. Dalam konteks bisnis, untuk memenuhi karyawan kita yang ada pada di tahap ini, apa yang kita bisa lakukan adalah untuk memberi mereka kesempatan untuk menggunakan keterampilan - keterampilan baru atau tantangan yang dapat membantu mereka belajar dan berkembang. 
Menurut Abraham Maslow, kebutuhan semua orang adalah seperti yang diatas. Sebelum mau memikirkan kebutuhan yang di level - level berikut, kita harus memenuhi kebutuhan di level sebelumnya terlebih dahulu. Namun harus diingat bahwa kebutuhan semua orang tidak sama; walaupun kebutuhan semua orang harus dipenuhi, apa yang mereka anggap cukup dapat berbeda. Contoh yang sering digunakan adalah Vincent van Gogh, pelukis terkenal asal belanda. Selama hidupnya, ia terkenal akan tidak memiliki banyak dan hanya memiliki keinginan untuk melukis. Banyak yang mengatakan bahwa, dalam kasus ini, ia sudah ada di tahap terakhir dari hierarki kebutuhan Maslow walaupun kebutuhan lainnya tidak terpenuhi; dia tidak memiliki banyak teman, komunitas sosialnya tidak menganggap dia sebagai warga yang memenuhi kewajibannya, dan kebutuhan fisiologinya pun sangat mendasar. Menurut Maslow, dalam kasus ini, bukanlah kebutuhan - kebutuhan lainnya belum terpenuhi, melainkan mereka sudah terpenuhi makanya Vincent van Gogh bisa memiliki kebutuhan akan aktualisasi sendiri, yaitu mengembangkan dan menjual lukisan yang dia buat. Kebutuhan yang dimiliki van Gogh sudah terpenuhi karena menurut dia, untuk hidup memiliki kebutuhan dasar saja sudah cukup. Ia tidak menginginkan persahabatan maka kebutuhan sosialnya sudah terpenuhi, ia tidak merasa takut maka kebutuhan akan keamanannya sudah terpenuhi, dan begitu juga kebutuhan lainnya. Bagi seseorang, memiliki 1 atau 2 interaksi bersama teman mereka perminggu saja sudah cukup untuk kebutuhan sosialnya, namun bagi orang lain mereka harus berinteraksi setiap hari untuk memuaskan kebutuhan sosialnya. Semua orang akan memiliki tingkat kebutuhan yang berbeda dan agar kita dapat memotivasikan karyawan kita, sebagai pebisinis, kita harus bisa mengerti mereka. Setelah kita mengerti kebutuhan mereka, barulah kita bisa memotivasi mereka.

Digital telah berada dimana mana ini merupakan dampak dari berkembangnya ilmu pengetahuan dan teknologi berhasil merubah pola hidup. Industry 4.0, AI, Cloud computing, the internet of everything, $3 d$ printing, social networking, ubiquitous connectivity dan big data merupakan hal baru yang telah berhasil merubah cara individu ataupun perusahaan dalam beraktifitas. Perubahan teknologi digital telah mengubah cara individu berinteraksi dengan bisnis dan satu sama lain. Modernisasi proses informasi dan komunikasi telah menjadi kekuatan pendorong evolusi sosial. Ini telah menciptakan generasi individu yang paling sosial dan terhubung dalam sejarah.

Dalam beberapa tahun terakhir digital memicu berubahnya akselerasi persaingan, kompetisi digital, ekspektasi konsumen dan adaptasi digital di beberapa jenis industri telah terdistrupsi cara berbisnisnya, perusahaan industri healtcare juga akan berubah untuk beradaptasi akan persaingan maupun keinginan konsumen, maka individu maupun organisasi memerlukan skill atau kemampuan baru. CPD adalah cara orang mempertahankan pengetahuan dan keterampilan yang berkaitan dengan kehidupan profesional mereka serta mengupgrade dengan hal hal baru. CPD dapat memanifestasikan dirinya dalam berbagai bentuk dari kursus pendidikan formal hingga pembelajaran melalui praktik kerja sehari-hari. Dalam bentuknya yang paling mudah dikenali, CPD mungkin memperbarui pengetahuan profesional melalui kursus singkat dan formal oleh kelompok-kelompok pekerjaan. 


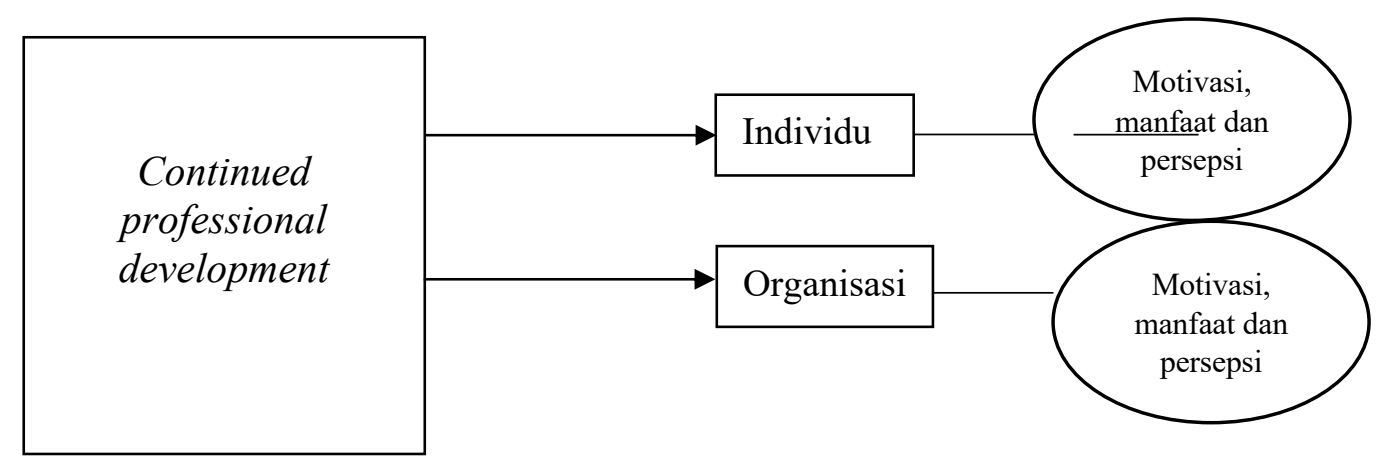

Gambar 2. continued professional development dalam industri healtcare

Continued professional development adalah serangkaian kegiatan pembelajaran yang membantu para profesional untuk mempertahankan dan meningkatkan pengetahuan mereka sepanjang kehidupan profesional mereka sehingga mereka dapat berlatih dengan aman, efektif dan legal dalam memberikan perawatan yang berkualitas (Burrow, 2016). Bahkan disebutkan ada manfaat bagi perawat, pasien, dan rumah sakit(organisasi/perusahaan).

Berdasarkan rumusan masalah, pembahasan dalam teori, kerangka berpikir dan kerangka konsep yang telah diuraikan, maka dapat diajukan hipotesis penelitian seperti dibawah ini.

$\mathrm{H}_{1}$ : Ada pengaruh continued professional development dalam individu di industri healtcare

$\mathrm{H}_{2}$ : Ada pengaruh continued professional development dalam organisasi di industri healtcare

\section{METODE PENELITIAN}

Penelitian ini merupakan penelitian kuantitatif melalui pendekatan cross sectional yaitu variabel penelitian diukur atau dikumpulkan dalam satu waktu artinya mengadakan pengamatan hanya sekali terhadap beberapa variabel dan waktu bersamaan. Lokasi penelitian adalah Rumah Sakit Bali Royal Hospital. Pengambilan data penelitian dilaksanakan selama 2 bulan yakni bulan Mei sampai bulan Juni 2020. Ruang lingkup penelitian adalah Bisnis Digital yang berkaitan tentang Continued professional development dalam industri healtcare. Penelitian ini mengetahui tentang Continued professional development dalam industri healtcare.

Populasi target penelitian ini adalah tenaga medis dan tenaga manager dilingkungan sedangkan populasi terjangkaunya adalah tenaga medis dan tenaga manager di Rumah Sakit Bali Royal Hospital sejumlah 107 orang. Sampel adalah bagian dari populasi yang dipilih dengan cara tertentu sehingga dianggap dapat mewakili populasinya (Sudigdo \& Ismael, 2008). Tenaga medis dan tenaga manager yang dijadikan sampel tersebut sebelumnya harus memenuhi kriteria inklusi dan eksklusi. Adapun kriteria inklusinya adalah sebagai berikut: (1) Tenaga medis yang masih aktif di lingkungan Rumah Sakit Bali Royal Hospital. (2) Tenaga medis yang bersedia menjadi responden yang dibuktikan dengan penandatanganan 
formulir persetujuan responden. Teknik pengambilan sampel yaitu teknik sampel jenuh, maka jumlah sampel pada penelitian ini adalah 107 orang.

Variabel penelitian ini Continued professional development, motivasi, persepsi dan manfaat. Definisi operasional masing masing variabel penelitian antara lain Continued professional development atau pengembangan profesional berkelanjutan merupakan cara yang profesional untuk mempertahankan pengetahuan dan keterampilan yang diperlukan dalam pekerjaan. Motivasi adalah dorongan yang dimiliki seseorang untuk mencapai sesuatu dengan ketekunan dan keyakinan. Persepsi adalah merupakan kesan yang diperoleh oleh individu melalui panca indera kemudian di analisa (diorganisir), diintepretasi dan kemudian dievaluasi, sehingga individu tersebut memperoleh makna. Manfaat adalah merupakan hal yang berguna/hasil dari sesuatu.

Instrumen yang digunakan dalam penelitian ini adalah kuesioner yang berisi pertanyaan terstruktur untuk mengukur variabel yang diteliti yaitu berisikan tentang karakteristik sosio-demografis (umur, jenis kelamin, status dan pekerjaan), manfaat, motifasi dan continued professional development dalam industri healtcare. Pengumpulan data dimulai dari pengurusan ijin dan administrasi lainnya yang dibutuhkan. Pengumpulan data primer dilakukan dengan merekrut 2 orang tenaga interviewer (pewawancara) dari tenaga medis dan tenaga manajerial yang dikoordinir oleh peneliti kemudian dilakukan pelatihan pengisian kuesioner untuk penyamaan persepsi antara peneliti dan pewawancara serta dilakukan uji coba survei oleh interviewer (pewawancara) kepada beberapa responden. Tenaga interviewer (pewawancara) mendapatkan insentif selama proses penelitian. Data primer dikumpulkan oleh peneliti bersama interviewer dengan melakukan wawancara dengan menggunakan kuesioner terstruktur kepada responden.

Teknik Analisis Data adalah suatu metode atau cara untuk mengolah sebuah data menjadi informasi sehingga karakteristik data tersebut menjadi mudah untuk dipahami dan juga bermanfaat untuk menemukan solusi permasalahan, yang tertutama adalah masalah yang tentang sebuah penelitian. Atau analisis data juga bisa diartikan sebagai kegiatan yang dilakukan untuk merubah data hasil dari sebuah penelitian menjadi informasi yang nantinya bila dipergunakan untuk mengambil sebuah kesimpulan yaitu analisis regresi sederhana.

Tujuan dari analisis data adalah untuk mendeskripsikan sebuah data sehingga bisa di pahami, dan juga untuk membuat kesimpulan atau menarik kesimpulan mengenai karakteristik populasi yang berdasarkan data yang diperoleh dari sampel, yang biasanya ini dibuat dengan dasar pendugaan dan pengujian hipotesis.

Data penelitian ini akan di olah menggunakan statistik deskriptif, Statistika deskriptif merupakan suatu metode yang berhubungan dengan pengumpulan atau penyajian data sampai memberi informasi yang berguna. Mengenai data dengan statistik deskriptif peneliti perlu memperhatikan terlebih dahulu jenis datanya. Jika peneliti mempunyai data diskrit, penyajian data yang dapat dilakukan adalah mencari frekuensi mutlak, frekuensi relative (mencari persentase), serta mencari ukuran tendensi sentralnya yaitu: mode, median dan mean (lebih lanjut lihat Arikunto, 1993: 363). 


\section{HASIL DAN PEMBAHASAN}

Tabel 1.

Karakteristik Responden

\begin{tabular}{|c|c|c|c|}
\hline \multirow{3}{*}{ No } & \multirow{3}{*}{ Jenis Kelamin } & \multirow{2}{*}{\multicolumn{2}{|c|}{ Jumlah }} \\
\hline & & & \\
\hline & & Orang & Persentase (\%) \\
\hline 1 & Laki-Laki & 60 & 56,1 \\
\hline \multirow[t]{2}{*}{2} & Perempuan & 47 & 43,9 \\
\hline & Jumlah & 107 & 100 \\
\hline \multirow{2}{*}{ No } & \multirow{2}{*}{ Tingkat Umur (Tahun) } & \multicolumn{2}{|c|}{ Jumlah } \\
\hline & & Orang & Persentase (\%) \\
\hline 1 & $21-30$ & 59 & 55,1 \\
\hline 2 & $31-40$ & 17 & 15,9 \\
\hline 3 & $41-50$ & 12 & 11,2 \\
\hline \multirow[t]{2}{*}{4} & $51-60$ & 19 & 17,8 \\
\hline & Jumlah & 107 & 100 \\
\hline \multirow{2}{*}{ No } & \multirow{2}{*}{ Tingkat Pendidikan } & \multicolumn{2}{|c|}{ Jumlah } \\
\hline & & Orang & Persentase (\%) \\
\hline 1 & Diploma & 67 & 62,6 \\
\hline \multirow[t]{2}{*}{2} & Sarjana & 40 & 37,4 \\
\hline & Jumlah & 107 & 100 \\
\hline \multirow{2}{*}{ No } & \multirow{2}{*}{ Masa Kerja (Tahun) } & \multicolumn{2}{|c|}{ Jumlah } \\
\hline & & Orang & Persentase $(\%)$ \\
\hline 1 & $1-5$ & 57 & 53,3 \\
\hline 2 & $6-10$ & 16 & 15 \\
\hline 3 & $11-15$ & 24 & 22,4 \\
\hline 4 & $16-20$ & 8 & 7,5 \\
\hline \multirow[t]{2}{*}{5} & $>20$ & 2 & 1,7 \\
\hline & Jumlah & 107 & 100 \\
\hline
\end{tabular}

Responden dalam penelitian ini berjumlah 50 orang. Dari hasil penelitian yang dilakukan terhadap tenaga medis dan tenaga manager di Rumah Sakit Bali Royal Hospital, maka dapat diketahui gambaran karakteristik responden yang meliputi empat aspek yaitu jenis kelamin, tingkat umur, tingkat pendidikan dan masa kerja. Tabel 1. menunjukkan bahwa karakteristik responden tenaga medis dan tenaga manager di Rumah Sakit Bali Royal Hospital.

Tabel 1. menunjukkan bahwa sebagian besar responden, yaitu sebesar $55,1 \%$ berasal dari kelompok usia 21-30 tahun dan diikuti oleh responden berusia 31-40 tahun sebesar 15,9\%. Pada Tabel 1. menunjukkan bahwa pada penelitian ini untuk jenis kelamin laki-laki lebih banyak sebagai responden, yaitu sebesar 56,1\% dan untuk jenis kelamin perempuan sebesar $43,9 \%$ yang menjadi responden. Faktor jenis kelamin perlu diperhatikan karena berkaitan dengan kemampuan karyawan dalam menjalankan dan menyelesaikan pekerjaan dengan cepat dan tepat sehingga ada keseimbangan antara guru laki-laki dan perempuan.

Berdasarkan pengelompokan dari tingkat pendidikan, yang menjadi mayoritas adalah responden dengan tingkat pendidikan Diploma sebesar 62,6\% dan responden dengan tingkat pendidikan Sarjana sebesar 37,4\%. Tingkat pendidikan responden merupakan salah satu penentu kualitas sumber daya manuasia. 
Berdasarkan masa kerja diketahui mayoritas penelitian ini memiliki masa kerja 1-5 tahun yaitu sebesar 53,3\%. Selanjutnya responden dengan masa kerja 11-15 tahun yaitu sebesar 22,4\%, 6-10 tahun sebesar 15\%, 16 - 20 tahun sebesar 7,5\% dan $>20$ tahun sebesar $1,7 \%$. Masa kerja adalah periode waktu yang dilalui oleh tenaga medis dan tenaga manager di Rumah Sakit Bali Royal Hospital dalam bekerja.

Sebelum menganalisis data, terlebih dahulu dilakukan uji validitas dan reliabilitas terhadap data yang diperoleh dari instrumen penelitian. Jika instrumen penelitian secara statistik dinyatakan valid dan reliable berarti instrumen layak digunakan sehingga mampu mengukur variabel sebagaimana mestinya. Sesuai dengan yang ditampilkan pada Tabel 2. ini berarti bahwa alat pengambil data berupa kuesioner hasilnya adalah valid.

Tabel 2.

Uji Validitas Instrumen

\begin{tabular}{ccccc}
\hline \multirow{2}{*}{ No } & Variabel & $\begin{array}{c}\text { Item } \\
\text { Pernyatan }\end{array}$ & $\begin{array}{c}\text { Korelasi } \\
\text { Item Total }\end{array}$ & Keterangan \\
& & X1.1 & 0,784 & Valid \\
& & X1.2 & 0,601 & Valid \\
1 & $\mathrm{X}$ & $\mathrm{X} 1.3$ & 0,650 & Valid \\
& & $\mathrm{X} 1.4$ & 0,725 & Valid \\
\hline \multirow{3}{*}{2} & $\mathrm{Y} 2.1$ & 0,832 & Valid \\
& & Y1.2 & 0,564 & Valid \\
& & Y1.3 & 0,878 & Valid \\
& & Y1.4 & 0,644 & Valid \\
& & Y1.5 & 0,626 & Valid \\
\hline \multirow{2}{*}{3} & & Y2.1 & 0,878 & Valid \\
& & Y2.2 & 0,601 & Valid \\
& & Y2.3 & 0,650 & Valid \\
& & Y2.4 & 0,784 & Valid \\
\hline
\end{tabular}

Sumber : Data diolah, 2020

Tabel 2. menunjukkan bahwa seluruh koefisien korelasi dari indikator variabel yang diuji nilainya lebih besar dari $0,30(\mathrm{r}>0,3)$. Hasil tersebut menunjukkan bahwa seluruh indikator yang terdapat pada penelitian ini terbukti valid.

Uji reliabilitas digunakan untuk mengukur konsistensi suatu variabel pada penelitian. Instrumen dikatakan reliabel untuk mengukur variabel bila memiliki nilai Cronbach Alpha $>0,60$. Hasil uji reliabilitas penelitian ini ditunjukkan dalam Tabel 3. berikut ini:

Tabel 3.

Hasil Uji Reliabilitas

\begin{tabular}{ccc}
\hline Variabel & Cronbach's Alpha & Keterangan \\
\hline$(\mathrm{X})$ & 0,783 & Reliabel \\
$(\mathrm{Y} 1)$ & 0,793 & Reliabel \\
$(\mathrm{Y} 2)$ & 0,727 & Reliabel \\
\hline Sumber : Data diolah, 2020 & &
\end{tabular}

Tabel 3. menunjukkan masing-masing nilai Cronbach's Alpha pada tiap instrumen tersebut lebih besar dari 0,6 (Cronbach's Alpha > 0,6). Hal tersebut 
menunjukkan bahwa semua instrumen reliabel sehingga dapat digunakan untuk melakukan penelitian.

Model regresi dikatakan model yang baik apabila dalam model tersebut bebas dari asumsi klasik statistik. Suatu model regresi linear berganda secara teoritis akan menghasilkan nilai parameter penduga yang tepat bila memenuhi persyaratan asumsi klasik regresi, yaitu: uji normalitas, multikolinearitas, dan heteroskedastisitas.

Pada penelitian ini pengujian normalitas dilakukan menggunakan analisis grafik histogram, normal probability plot dan analisis statistik One-Sample Kolmogorov-Smirnov, yaitu dengan membandingkan Kolmogorov-Smirnov hitung dengan Kolmogorov-Smirnov tabel. Adapun hasil analisis menggunakan grafik histogram dan normal probability plot ditampilkan pada Gambar 7 dan Gambar 8 berikut:

\section{Histogram}

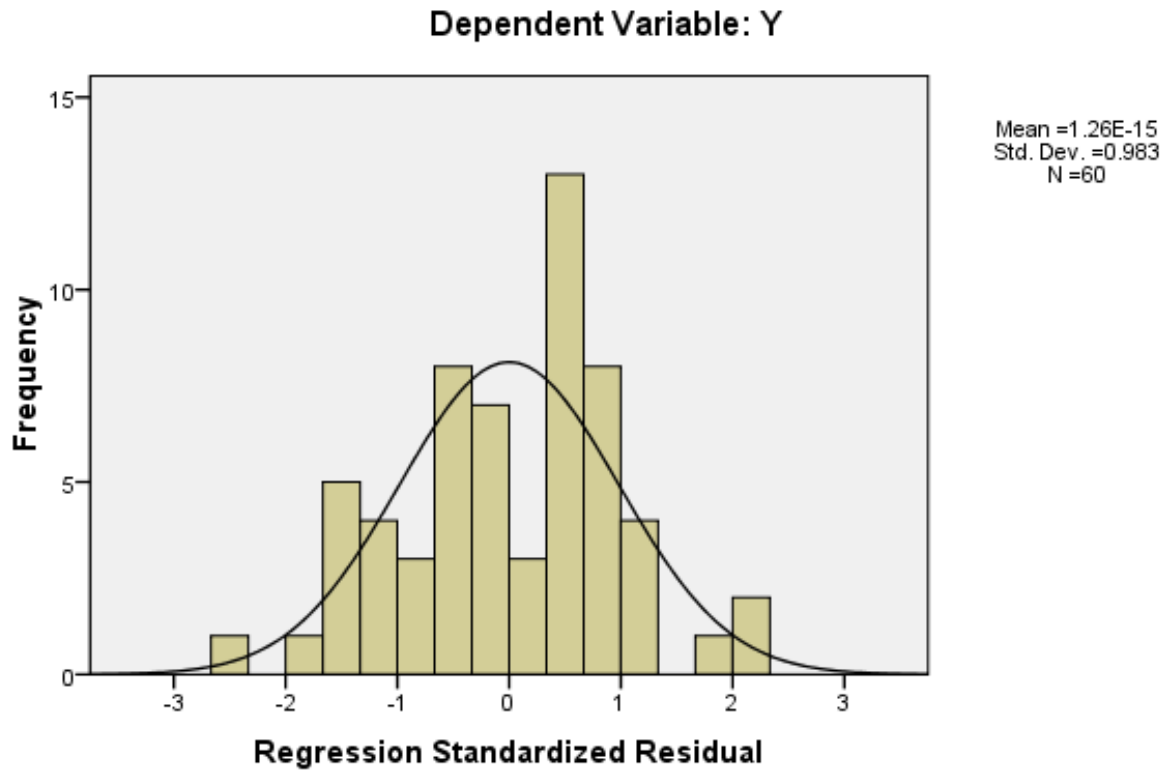

Gambar 3. Uji Normalitas (Grafik Histogram)

Sumber : Data diolah, 2020

Grafik histogram yang ditunjukkan pada Gambar 3. menunjukkan bahwa adanya pola distribusi normal sebab memperlihatkan grafik yang mengikuti sebaran kurva normal yang ditunjukkan dengan kurva yang berbentuk lonceng menghadap ke atas 


\section{Normal P-P Plot of Regression Standardized Residual}

\section{Dependent Variable: $Y$}

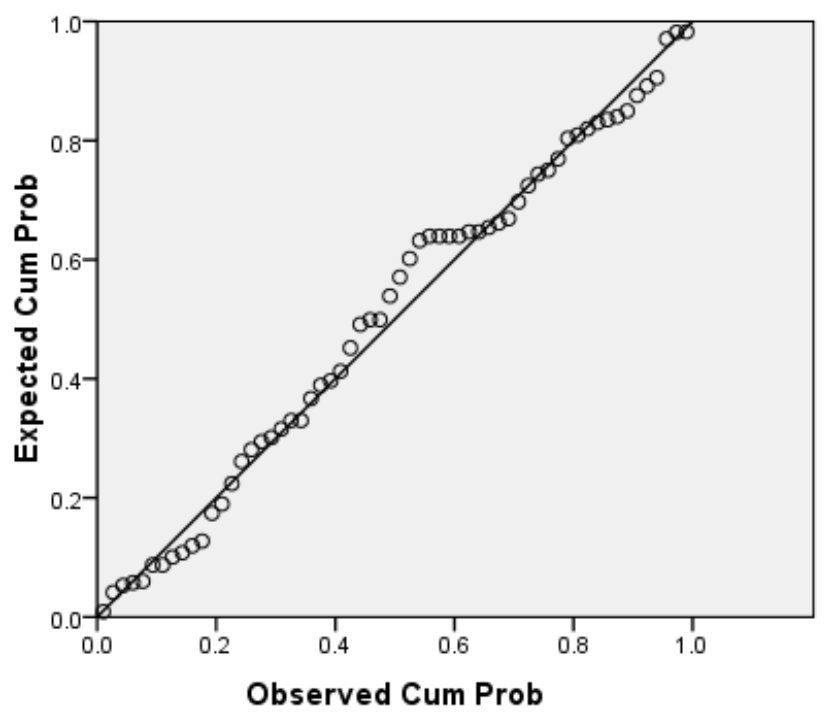

Gambar 4. Uji Normalitas (Normal Probability Plot)

Sumber : Data diolah, 2020

Grafik normal probability plot yang ditunjukkan pada Gambar 4. menunjukkan bahwa adanya pola distribusi normal dimana data berupa plot menyebar disekitar garis diagonal dan mengikuti arah garis diagonal.

Tabel 4.

Uji Normalitas

\begin{tabular}{llr}
\hline \multicolumn{2}{c}{ One-Sample Kolmogorov-Smirnov Test } & $\begin{array}{c}\text { Unstandardized } \\
\text { Residual }\end{array}$ \\
\hline $\mathrm{N}$ & & 107 \\
Normal Parameters ${ }^{\mathrm{a}, \mathrm{b}}$ & Mean & .0000000 \\
& Std. Deviation & 1.14693719 \\
Most Extreme Differences & Absolute & .101 \\
& Positive & .060 \\
& Negative & -.101 \\
Kolmogorov-Smirnov Z & & .870 \\
Asymp. Sig. (2-tailed) & & .757 \\
Sumber : Data diolah, 2020 & &
\end{tabular}

Selain menggunakan analisis grafik tersebut, uji normalitas juga dilakukan melalui analisis One-Sample Kolmogorov-Smirnov pada uji non parametrik. 
Adapun hasil uji One-Sample Kolmogorov-Smirnov dapat ditampilkan dalam Tabel 4.

Berdasarkan uji normalitas dengan menggunakan One-Sample KolmogorovSmirnov Test yang ditampilkan pada Tabel 4 tersebut menunjukkan bahwa besarnya nilai Kolmogorov-Smirnov adalah sebesar 0,870. Nilai Kolmogorov-Smirnov tersebut lebih besar dibandingkan dengan nilai Kolmogorov-Smirnov Tabel sebesar 0,05 maka $\mathrm{H}_{\mathrm{o}}$ diterima yang mengindikasikan bahwa data yang digunakan pada penelitian ini terdistribusi normal, sehingga dapat disimpulkan bahwa model memenuhi asumsi normalitas.

Uji multikolinearitas dilakukan untuk melihat apakah terdapat korelasi yang sempurna antar variabel bebas yang digunakan pada penelitian ini. Pengujian multikolinearitas dilakukan dengan menganalisis nilai tolerance dan nilai VIF. Nilai tolerance dan nilai $V I F$ digunakan untuk mengukur variabilitas variabel independen atau hubungan antar variabel independen, jika nilai tolerance kurang dari 0,10 atau nilai $V I F$ lebih dari 10 maka menunjukkan adanya multikolinearitas. Adapun nilai tolerance dan nilai VIF ditunjukkan pada Tabel 5 berikut:

Tabel 5.

Uji Multikolinieritas

(Tolerance dan Variance Inflation Factor)

\begin{tabular}{lccc}
\hline \multicolumn{4}{c}{ Coefficients $^{\mathbf{a}}$} \\
\hline \multirow{2}{*}{ Model } & & \multicolumn{2}{c}{ Collinearity Statistics } \\
\cline { 2 - 4 } & & Tolerance & VIF \\
\hline \multirow{2}{*}{1} & $\mathrm{X}$ & 0.998 & 1.002 \\
\cline { 2 - 4 } & & & \\
\hline
\end{tabular}

Sumber : Data diolah, 2020

Berdasarkan Tabel 5. tersebut ditunjukkan bahwa tidak terdapat variabel bebas yang memiliki nilai tolerance kurang dari 0,10 dan juga tidak ada variabel bebas yang memiliki nilai VIF lebih dari 10. Maka dari pada itu model regresi bebas dari gejala multikoleniaritas.

Pengujian heteroskedastisitas dilakukan melalui metode glesjer dan dengan grafik scatterplot. Metode glesjer meregresikan model regresi untuk mendapatkan nilai residualnya, kemudian nilai residual tersebut diabsolutkan dan dilakukan regresi dengan semua variabel independen. Bila terdapat variabel independen yang berpengaruh secara signifikan terhadap residual absolut maka terjadi heteroskedastisitas pada model regresi ini. Tabel 6. menunjukkan hasil perhitungan statistik dengan metode glesjer.

Berdasarkan Tabel 6., ditunjukkan bahwa masing-masing model memiliki nilai signifikansi lebih besar dari 5\%. Hal ini menunjukkan bahwa variabel bebas yang digunakan pada penelitian ini tidak berpengaruh secara signifikan terhadap variabel terikatnya yaitu absolute error, maka dari itu, penelitian ini bebas dari gejala heteroskedastisitas. Adapun pengujian melalui grafik scatterplot ditunjukkan pada Gambar 5. 
Tabel 6.

Uji Heteroskedastisitas (Uji Glesjer)

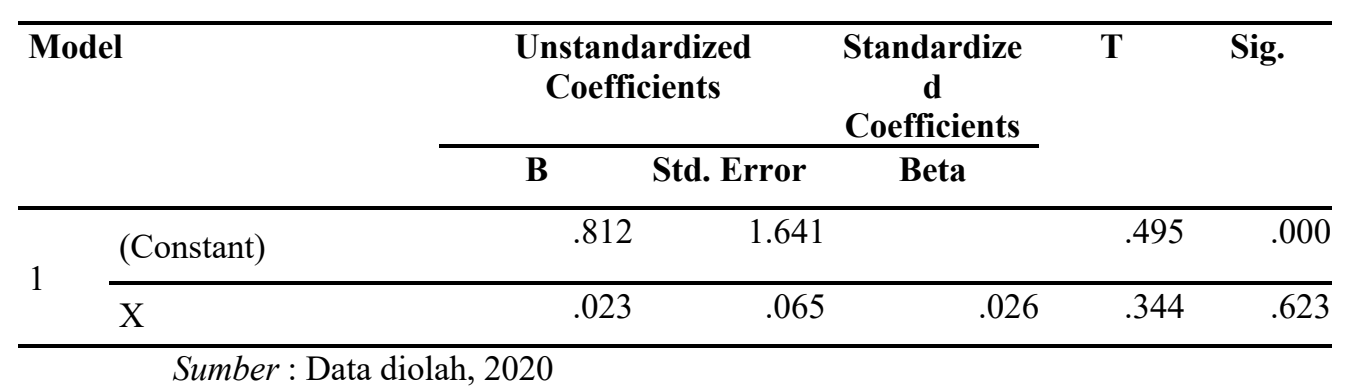

Scatterplot

Dependent Variable: $Y$

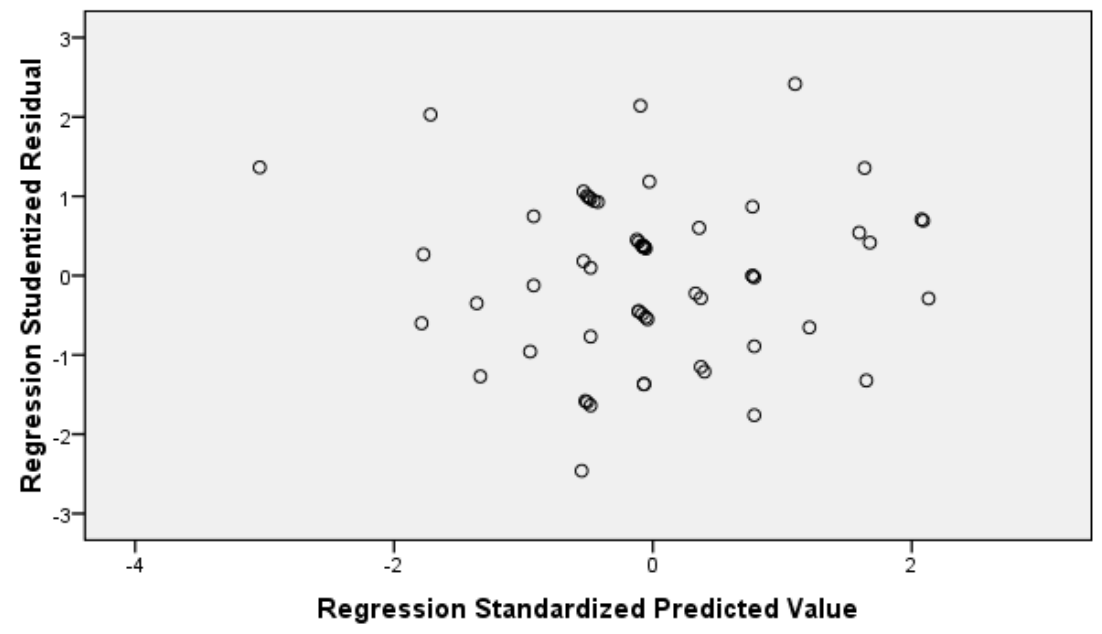

Gambar 5. Uji Heteroskedastisitas (Grafik Scatterplot)

Sumber : Data diolah, 2020

Berdasarkan Gambar 5. ditunjukkan bahwa titik-titik pada gambar menyebar secara acak baik diatas maupun dibawah angka 0 pada sumbu Y. Oleh karena itu, dapat disimpulkan bahwa tidak terdapat gejala heteroskedastisitas pada model regresi ini.

Model analisis regresi linear berganda digunakan untuk mendapat koefisien regresi yang akan menentukan apakah hipotesis yang dibuat akan diterima atau ditolak. Hasil analisis ini mengacu pada hasil pengaruh variabel komunikasi (X) terhadap variabel Individu $\left(\mathrm{Y}_{1}\right)$ dan organisasi $\left(\mathrm{Y}_{2}\right)$ pada tenaga medis dan tenaga manager di Rumah Sakit Bali Royal Hospital. Adapun hasil analisis regresi dengan program Statitical Pacage of Social Science (SPSS) versi 20.0 for Windows dapat dilihat pada Tabel 7. berikut. 
Tabel 7.

Rangkuman Hasil Analisis Regresi Linear Berganda1

\begin{tabular}{|c|c|c|c|c|c|}
\hline \multicolumn{2}{|c|}{ Variabel } & \multicolumn{2}{|c|}{ Koefisien Regresi } & \multirow{2}{*}{$\mathbf{T}$} & \multirow{2}{*}{ Sig } \\
\hline & & B & Std. Error & & \\
\hline \multicolumn{2}{|c|}{ Continued professional development } & 0.023 & 0.068 & 0.344 & 0.002 \\
\hline (Constant) & $: 0.812$ & & & & \\
\hline F Statistik & $: 62.054$ & & & & \\
\hline Sig F & $: 0.000$ & & & & \\
\hline $\mathrm{R}^{2}$ & $: 0.685$ & & & & \\
\hline $\mathrm{R}$ & : 0.828 & & & & \\
\hline
\end{tabular}

Berdasarkan Tabel 7. dapat ditulis persamaan regresi linear berganda sebagai berikut.

$$
\mathrm{Y}=0.812+0.023 \mathrm{X}_{1}+\mathbf{e}
$$

Dimana :

$$
\begin{aligned}
& \mathrm{Y}_{1}=\text { Individu } \\
& \mathrm{X}=\text { Continued professional development }
\end{aligned}
$$

Persamaan regresi linear berganda tersebut menunjukkan arah masingmasing variabel bebas terhadap variabel terikatnya. Persamaan regresi linear berganda tersebut dapat diuraikan sebagai berikut :

Nilai constant 0,812 menunjukan apabila continued professional development bernilai sama dengan 0 (nol) maka motivasi, manfaat dan persepsi secara individu di Rumah Sakit Bali Royal Hospital bernilai sebesar 0,812.

$\mathrm{X}=+0,023$ menunjukkan bahwa continued professional development berpengaruh positif terhadap motivasi, manfaat dan persepsi secara individu di Rumah Sakit Bali Royal Hospital, apabila continued professional development meningkat 1 satuan maka motivasi, manfaat dan persepsi secara individu di Rumah Sakit Bali Royal Hospital, sebesar 0,023.

\begin{tabular}{|c|c|c|c|c|c|}
\hline & & \multicolumn{2}{|c|}{ Koefisien Regresi } & \multirow{2}{*}{$\mathbf{T}$} & \multirow{2}{*}{ Sig } \\
\hline & & B & Std. Error & & \\
\hline \multicolumn{2}{|c|}{ Continued professional development } & 0.721 & 0.065 & 11.127 & 0.000 \\
\hline (Constant) & $: 0.812$ & & & & \\
\hline F Statistik & : 62.054 & & & & \\
\hline Sig F & : 0.000 & & & & \\
\hline $\mathrm{R}^{2}$ & $: 0.685$ & & & & \\
\hline $\mathrm{R}$ & $: 0.828$ & & & & \\
\hline
\end{tabular}

Tabel 8.

Rangkuman Hasil Analisis Regresi Linear Berganda2 berikut.

Berdasarkan Tabel 8. dapat ditulis persamaan regresi linear berganda sebagai

$$
\mathrm{Y}=0.812+0.721 \mathrm{X}_{1}+\mathbf{e}
$$


Dimana :

$$
\begin{aligned}
& \mathrm{Y}_{2}=\text { Organisasi } \\
& \mathrm{X}=\text { Continued professional development }
\end{aligned}
$$

Persamaan regresi linear berganda tersebut menunjukkan arah masingmasing variabel bebas terhadap variabel terikatnya. Persamaan regresi linear berganda tersebut dapat diuraikan sebagai berikut :

Nilai constant 0,812 menunjukan apabila continued professional development bernilai sama dengan 0 (nol) maka motivasi, manfaat dan persepsi secara organisasi di Rumah Sakit Bali Royal Hospital bernilai sebesar 0,812.

$\mathrm{X}=+0,721$ menunjukkan bahwa continued professional development berpengaruh positif terhadap motivasi, manfaat dan persepsi secara organisasi di Rumah Sakit Bali Royal Hospital, apabila continued professional development meningkat 1 satuan maka motivasi, manfaat dan persepsi secara organisasi di Rumah Sakit Bali Royal Hospital sebesar 0,721 .

Analisis derteminasi dilakukan untuk mengetahui sejauh mana variasi variabel bebas yaitu $\mathrm{X}$ terhadap variabel $\left(\mathrm{Y}_{1}\right.$ dan $\left.\mathrm{Y}_{2}\right)$. berdasarkan hasil spss yang dapat dilihat pada Tabel 9.

Tabel 9.

Hasil Analisis Determinasi

\begin{tabular}{lcccr}
\hline Model & R & R Square & $\begin{array}{c}\text { Adjusted R } \\
\text { Square }\end{array}$ & $\begin{array}{c}\text { Std. Error of the } \\
\text { Estimate }\end{array}$ \\
\hline 1 & $.928^{\mathrm{a}}$ & .785 & .674 & 1.167 \\
\hline Sumber : Data diolah, 2020 & & & & \\
\hline
\end{tabular}

Berdasarkan Tabel 9. tersebut dapat diketahui bahwa nilai $\mathrm{R}$ square $\left(\mathrm{R}^{2}\right)=$ 0,785. Adapun analisis menggunakan rumus sebagai berikut:

$$
\begin{aligned}
& D=R^{2} \times 100 \% \ldots \ldots \\
& D=0.785 \times 100 \% \\
& D=78.5 \%
\end{aligned}
$$

Berdasarkan hasil tersebut diketahui bahwa nilai $\mathrm{R}^{2}=78,5$ persen, yang berarti bahwa sebesar 78,5 persen motivasi, manfaat dan persepsi secara individu dan organisasi di di Rumah Sakit Bali Royal Hospital dipengaruhi oleh variabel continued professional development sisanya sebesar 21,5 persen dipengaruhi oleh variabel lain yang tidak diteliti pada penelitian ini.

Motivasi intrinsik untuk partisipasi CPD adalah motivasi diri dan kepuasan pribadi, perbarui pengetahuan terkini dan pembelajaran keterampilan baru (James \& Francis, 2011). Dalam penelitian (Panthi \& Pant, 2018) mengungkapkan bahwa faktor intrinsik terpenting yang memotivasi tenaga kesehatan adalah keinginan 
untuk meningkatkan tingkat pendidikan, peluang promosi peningkatan finansial dan keamanan kerja sedangkan faktor motivasi ekstrinsik adalah dorongan teman sebaya, dukungan keluarga atau pengusaha dan pembaruan izin. Penting untuk memahami faktor motivasi di balik keterlibatan perawat dalam kegiatan pembelajaran untuk secara efektif meningkatkan pengembangan profesional.

Perwat melihat program CPD merupakan berharga dan menarik karena bersifat wajib dimiliki dalam industri healtcare dan membantu mereka mempertahankan pekerjaannya akibat dari perkembangan teknologi (Panthi \& Pant, 2018).

Manfaat pengembangan profesional lebih lanjut diakui oleh (Baxter et al., 2013), menyatakan bahwa pendidikan lanjutan merupakan aspek penting untuk praktik profesional dan promosi keselamatan yang pada akhirnya menjamin pengembangan karir praktisi kesehatan. Secara bersamaan, panduan kegiatan profesional berkelanjutan untuk memenuhi beragam kebutuhan pasien dan promosi kompetensi profesional. Ada peningkatan yang dirasakan dalam keterampilan psikomotor, kognitif, dan afektif bersama dengan peningkatan pengetahuan dan kesadaran tentang masalah terkait profesi setelah continued professional development wajib (James \& Francis, 2011).

Hasil utama dari kegiatan ini untuk perawat yang melaksanakan CPD terus menerus adalah peningkatan praktik dan pemantapan perubahan yang lebih positif. CPD bertujuan untuk mempertahankan dan memperluas pengetahuan dan keahlian perawat yang ada sehingga mendorong kualitas pribadi dan profesional tenaga kesehatan, kelayakan kerja di masa depan, dan kemampuan untuk melakukan pekerjaan saat ini seperti yang dikemukakan oleh Bindon (2017). Panthi et al; 2018 menyatakan bahwa CPD meningkatkan efikasi diri perawat, pengambilan keputusan dan kapasitas berbagi informasi. Demikian pula, CPD memberikan kesempatan bagi para profesional perawatan kesehatan dengan meningkatkan komitmen profesional dan kepuasan kerja mereka.

Faktor motivasi ekstrinsik yang diidentifikasi adalah kualitas perawatan pasien, pengembangan kecerdasan dan peran, pemutakhiran pengetahuan, bukti kompetensi dan kebutuhan organisasi. Selain itu, ditemukan pula promosi pekerjaan, perolehan finansial, pengaturan cuti berbayar, peningkatan karir kegiatan CPD gratis, persyaratan sertifikasi, dan evaluasi peningkatan kinerja. (French et al., 2008). Studi menunjukkan bahwa ketika organisasi mendukung dalam hal cuti berbayar dan memahami pentingnya CPD, perawat termotivasi untuk berpartisipasi dalam kegiatan pembelajaran serta meningkatkan kepuasan kerja. Sikap positif terhadap CPD dari manajemen dan rekan memfasilitasi pembelajaran yang efektif (Panthi \& Pant, 2018). Kemudian di lanjutkan bahwa studi ini menemukan bahwa pendorong terlaksananya Continuing education adalah untuk meningkatkan kualitas perawatan, meningkatkan kompetensi klinis, keterampilan, kapasitas pengambilan keputusan klinis dan untuk memperoleh pengetahuan berbasis bukti dan persyaratan kredit.

Manusia senantiasa berpandangan untuk memperoleh dan memperbaharui ilmu dengan belajar. Dunia saat ini organisasi dituntut agar perawatan kesehatan untuk belajar seumur hidup di tempat kerja untuk memberikan layanan yang aman kepada klien/pasien dan meningkatkan kemampuan profesionalnya. Perawat 
menyadari fakta bahwa peralatan dan perangkat lunak terus berubah serta kurangnya dukungan teknis di tempat kerja dalam Panthi et al; 2018.

Pengembangan profesional berkelanjutan menguntungkan profesi perawat dan konsumen melalui peningkatan kepercayaan konsumen, citra publik dan lebih banyak kesempatan untuk memenuhi kebutuhan anggota (James \& Francis, 2011). Dilanjutkan (Baxter et al., 2013) bahwa partisipasi dalam CPD diperlukan untuk memberikan perawatan pasien yang aman dan berkualitas sehingga menghasilkan kepuasan pasien. Serta ketika perusahaan/organisasi terlibat dalam continued professional development, kualitas layanan akan meningkat. (James \& Francis, 2011) adalah untuk meningkatkan pemberian layanan kesehatan dan perawatan yang lebih baik untuk publik yang pada akhirnya mengarah pada pengembangan akhir dari pengetahuan profesional dan oleh karena itu merupakan tujuan strategis dari pemberi kerja. Panthi \& Pant (2018) berpendapat bahwa Organisasi mendapat manfaat dari pendidikan berkelanjutan staf mereka karena ada penyediaan perawatan pasien berkualitas tinggi melalui karyawan yang terampil yang meningkatkan sistem pemberian perawatan kesehatan secara keseluruhan di tingkat organisasi. Tingkat retensi pekerjaan atau komitmen kerja ditemukan lebih tinggi pada perawat yang menghargai pembelajaran di tempat kerja sebagai bagian penting dari pembelajaran seumur hidup. Studi juga mengungkapkan bahwa pembelajaran seumur hidup dicapai ketika pro dan kontra CPD dipertimbangkan.

\section{SIMPULAN}

Penelitian ini membahas tentang kesimpulan penelitian secara keseluruhan. Tujuan penelitian ini mengidentifikasikan CPD bagi individu dan organisasi, apa yang menjadi motivasi, persepsi dan manfaat bagi individu dan organisasi. Penelitian ini berusaha untuk mengetahui isu-isu tentang CPD. Dalam tinjauan pustaka ini, terbukti bahwa tenaga kesehatan harus terlibat dalam kegiatan CPD dan memperbaharui kompetensi mereka untuk mendapatkan skill dan pengetahuan yang dapat membantu pekerjaan. Tenaga kesehatan/individu bertanggung jawab untuk memenuhi tantangan profesi mereka dan menanggapi hambatan yang terusmenerus dalam sistem perawatan kesehatan meskipun tidak wajib untuk mengambil CPD. Organisasi bertanggung jawab untuk membuat budaya kerja yang berdampak positif, sehingga membuat peluang kegiatan CPD dapat diakses oleh tenaga kesehatan yang mengarah pada pengembangan skill dan pengetahuan yang sekiranya diperlukan untuk menghadapi revolusi industri 4.0.

Berdasarkan analisis dan pembahasan serta kesimpulan yang diperoleh, ada beberapa saran yang diajukan oleh penulis kepada pihak-pihak yang terkait dalam penelitian ini, diantaranya organisasi/perusahaan dalam industri healtcare diharapkan mengambil tanggung jawab untuk pengembangan kemampuan karyawan. Organisasi/perusahaan dalam industri healtcare diharapkan membuat program untuk meningkatkan kemampuan pegawai medis, tidak hanya memberi pengetahuan tentang medis tetapi memberikan program untuk penunjang pengetahuan lain yang dapat membantu dalam pekerjaan. Organisasi/perusahaan dalam industri healtcare diharapkan bisa meningkatkan kegiatan CPD. Karena saat ini memaksimalkan potensi staff dengan CPD dapat memberikan dampak positif 
bagi organisasi. Organisasi/perusahaan dalam industri healtcare diharapkan bisa lebih kreatif dan inovatif dalam melaksanakan kegiatan CPD serta harus memperhitungkan perkembangan revolusi industri 4.0. Karena kegiatan CPD yang dilakukan akan sangat berpengaruh terhadap kemampuan dan skill baru yang akan dimiliki oleh pegawai kedepannya. Organisasi/perusahaan dalam industri healtcare diharapkan bisa menyesuaikan program CPD pada pegawai supaya skill dan kemampuan baru dapat di aplikasikan pada kegiatan kerja sehari hari bisa diterima dengan baik. Saran bagi individu/karyawan dalam industri healtcare yaitu individu/karyawan dalam industri healtcare diharapkan memahami bahwa CPD merupakan investasi dalam pengembangan karir, Individu/karyawan dalam industri healtcare diharapkan memahami bahwa CPD meningkatkan kepercayaan diri dan memperkuat kredibilitas profesional untuk mempersiapkan diri untuk tanggung jawab yang lebih besar dan dapat melihat perkembangan dengan melacak pembelajaran, Individu/karyawan dalam industri healtcare diharapkan aktif untuk belajar yang membantu pekerjaan dengan mengakses pembelajaran secara online atau melalui perpustakaan. Bagi yang akan meneliti mengenai continued professional development dalam industri healtcare, dapat dilakukan dengan menambahkan variabel lainnya seperti online learning, traning, citra/merek serta moral pegawai.

\section{REFERENSI}

Baxter, P., DiCenso, A., Donald, F., Martin-Misener, R., Opsteen, J., \& Chambers, T. (2013). Continuing education for primary health care nurse practitioners in Ontario, Canada. Nurse Education Today, 33(4), 353-357. https://doi.org/10.1016/j.nedt.2012.07.018

Collin, K., Van der Heijden, B., \& Lewis, P. (2012). Continuing professional development. International Journal of Training and Development, 16(3), 155163. https://doi.org/10.1111/j.1468-2419.2012.00410.x

Deloitte. (2015). Survival Thought Digital Leadership.

Fleet, L. J., Kirby, F., Cutler, S., Dunikowski, L., Nasmith, L., \& Shaughnessy, R. (2008). Continuing professional development and social accountability: A review of the literature. Journal of Interprofessional Care, 22(SUPPL. 1), 1529. https://doi.org/10.1080/13561820802028360

Hariyati, R. T. S., \& Safril, S. (2018). The relationship between nurses' job satisfaction and continuing professional development. Enfermeria Clinica, 28, 144-148. https://doi.org/10.1016/S1130-8621(18)30055-X

James, A., \& Francis, K. (2011). Mandatory continuing professional education: What is the prognosis? Collegian, 18(3), 131-136. https://doi.org/10.1016/j.colegn.2011.03.001

Karban, R. (2015). Plant Learning and Memory. In: Plant Sensing and communication. the University of Chicago Press.

Khan, A. W. (2010). Continuing Professional Development (CPD); What should 
we do? Bangladesh Journal of Medical Education, 1(1), 37-44. https://doi.org/10.3329/bjme.v1i1.12857

Laal, M., \& Salamati, P. (2012). Lifelong learning; Why do we need it? Procedia Social and Behavioral Sciences, 31(2011), 399-403. https://doi.org/10.1016/j.sbspro.2011.12.073

Légaré, F., Freitas, A., Turcotte, S., Borduas, F., Jacques, A., Luconi, F., ... Labrecque, M. (2017). Responsiveness of a simple tool for assessing change in behavioral intention after continuing professional development activities. PLoS ONE, 12(5), 1-13. https://doi.org/10.1371/journal.pone.0176678

Lessing, A., \& Witt, M. De. (2007). The value of continuous professional development: Teachers' perceptions. South African Journal of Education, 27(1), 53-67.

M., P.-M. (2015). Continuing Professional Development, Using systematic reviews to inform nursing practice. Nursing Standard, 29, 52-58.

Moonasar, A., \& Underwood, P. (2018). Continuing Professional Development opportunities in Information and Communication Technology for academic librarians at the Durban University of Technology. South African Journal of Libraries and Information Science, 84(1), 47-55. https://doi.org/10.7553/84$1-1759$

Panthi, L. P., \& Pant, S. S. (2018). Continuous Professional Development in Healthcare. (May), 1-3.

R., G. (2010). Psychology: The Science of Mind and Behaviour (6th ed.). Hachette UK.

Schacter D.L., Gilbert. D.T., \& D.M, W. (2011). Psychology (2nd ed.). Worth Publishers.

Siagian, S. (2012). Teori Motivasi dan Aplikasinya. Jakarta: Rineka Cipta.

Taylor, L. (2016). How to Develop Your Healthcare Career: A Guide to Employability and Professional Development. Retrieved from https://books.google.co.id/books?hl=en\&lr=\&id=4PFmCgAAQBAJ\&oi=fnd $\&$ pg $=$ PP9\&dq $=$ Taylor $,+\mathrm{LE}+($ ed. $)+(2016),+$ How + to + Develop + Your + Healthc are+Career:+A+Guide+to+Employability+and+Professional+Development, + John+Wiley+\%26+Sons, +Incorporated,+Chicester.+Available+from:+ProQu est+Ebook+Central.+pp+69-

76\&ots $=5 \mathrm{~J} 9 \mathrm{JbEj} 1 \mathrm{Rx} \& \mathrm{sig}=62 \mathrm{vmqS6OHAK02146IsvzVFvDoYs \& redir}$ esc $=$ $\mathrm{y} \# \mathrm{v}=$ onepage $\& \mathrm{q} \& \mathrm{f}=$ false

Thomas, C. D. (2008). Cross-Cultural Management: Essential Concepts (first). SAGE.

Weerakkody, V., Osmani, M., Waller, P., Hindi, N., \& Al-Esmail, R. (2016). Situating Continuing Professional Development in Life Long Learning in 
E-Jurnal Manajemen, Vol. 10, No. 2, 2021 : 165-187

Qatar. International Journal of Business and Management, 11(11), 81. https://doi.org/10.5539/ijbm.v11n11p81 